\title{
Guest editorial for the special issue "Tectonics of Bay of Bengal and Arabian Sea with special emphasis on coastal and marine geohazards"
}

\author{
K. S. R. Murthy • A. K. Chaubey $・$ M. Radhakrishna
}

Received: 9 March 2011/Accepted: 9 March 2011/Published online: 23 March 2011

(C) Springer Science+Business Media B.V. 2011

The Indian Ocean, the third largest of the world's oceans, is comprised of diverse and complex tectonic features. The Arabian Sea and the Bay of Bengal, bordering the Indian Peninsula on west and east, respectively, constitute the northwestern and northeastern parts of the Indian Ocean. The evolution of Indian Ocean and the present morphology and tectonics of the bordering continental margins are the consequence of the breakup of Eastern Gondwanaland and subsequent seafloor spreading between the constituent continents viz., Madagascar, Seychelles, India, Antarctica, and Australia, since the Early Cretaceous. There were three main episodes in the disintegration of Gondwanaland (Storey 1995). The rifting started during the Early Jurassic, when Gondwanaland separated into eastern and western parts, causing a seaway separating South America-Africa from Madagascar-Seychelles-India-Antarctica-Australia-New Zealand. The second stage occurred in Early Cretaceous, with South America separating from an African-Indian plate and African-Indian plate itself separating from the Antarctica. Finally, the third stage occurred in Late Cretaceous when Australia and New Zealand got separated from Antarctica. Around this time, Madagascar separated from India, and the latter migrated northward.

The initial separation of India from Antarctica (130 Ma) was in a NW-SE direction, and around Late Cretaceous (90-80 Ma), a plate reorganization took place when this orientation changed essentially to N-S. The soft collision between India and Eurasia might have occurred around $59 \mathrm{Ma}$ (Paleocene-Eocene boundary), which resulted in the initiation of Himalayan uplift (Curray and Munasinghe 1989). The hard Continent-Continent collision

K. S. R. Murthy ( $₫)$

National Institute of Oceanography, Regional Centre, 176, Lawsons Bay,

Visakhapatnam 530017, India

e-mail: ksr@nio.org

A. K. Chaubey

National Institute of Oceanography, Dona Paula 403004, Goa, India

e-mail: chaubey@nio.org

M. Radhakrishna

Indian Institute of Technology, Bombay, Powai, Mumbai 400076, India

e-mail: mradhakrishna@iitb.ac.in 
with the Eurasian landmass occurred at about $15 \mathrm{Ma}$ (Middle Miocene). The massive uplift of Himalayas caused huge sediment influx into the adjoining ocean basins and formed the Indus Fan in the Arabian Sea and the Bengal Fan in the Bay of Bengal, the world's two largest Fan systems (Curray et al. 2003; Kolla 2007).

The earliest studies on the stratigraphy, structure, and tectonics of the northern Indian Ocean during the International Indian Ocean Expedition (IIOE: 1960-1965) evoked considerable interest on this tectonically complex region. Subsequent geophysical studies during the period from 1970 to this date, mainly by the National Institute of Oceanography, India, and also by other academic institutes and organizations led to the generation of several new concepts on the structure, tectonics, and geodynamic evolution of the Bay of Bengal and Arabian Sea region. Satellite altimetry derived free-air gravity data along with ship-borne gravity and magnetic data sets, integrated with multichannel seismic data during the last two decades, added significant new information on the breakup and spreading history of the Indian Ocean (Chaubey et al. 2002; Radha Krishna et al. 2002; Royer et al. 2002; Ramana et al. 2003; Krishna et al. 2009; Ajay et al. 2010). In contrast, studies related to marine geohazards are relatively sparse in the northern Indian Ocean.

The Indian plate consisting of the Indian subcontinent and the adjoining oceanic areas is sandwiched between the seismically active Himalayan belt in the north and the intense intraplate crustal deformation zone (Neprochnov et al. 1998; Krishna et al. 1998) in the equatorial region of the Central Indian Ocean. As a result, it is currently under intense regional compressive stress field. This is evident from the fact that during the last 50 years, the Peninsular India witnessed eight earthquakes of moderate magnitude, majority of them spatially coincident with paleo rifts and clustered around the preexisting structural features (Rajendran 2000). High-magnitude intraplate earthquakes of Killari $\left(M_{\mathrm{w}} 6.2,1993\right)$, Jabalpur $\left(M_{\mathrm{w}} 5.8,1997\right)$, and Bhuj $\left(M_{\mathrm{w}} 7.7,2001\right)$ have claimed several human lives, and moderate earthquakes in Kerala $(M 5.0,2000)$, Karnataka $(M 4.3,2001)$, and Tamil Nadu $(M 5.5,2001)$ in the southern peninsular India have created enough concern to understand the temporal and spatial behavior of seismically active faults and the nature and frequency of recurrence. The recent occurrence of earthquakes in coastal regions of East as well as West Coasts of India has invoked interest among the earth scientists to study the coastal seismicity in relation to morphological and tectonic lineaments associated with coastal and near-shore regions of the continental shelf (Murthy et al. 2010).

The Sumatra mega thrust earthquake $\left(M_{\mathrm{w}} 9.3\right)$ of December 26, 2004, the fifth largest earthquake since 1900 and the largest since the 1964 Alaska earthquake (Lay et al. 2005), caused devastating effect in the coastal areas of India and neighboring countries with regard to loss of life as well as property and has sent alarming signals to the earth and ocean science community on the need for a comprehensive study on the marine geohazards of the Bay of Bengal and the Arabian Sea. This earthquake, with its epicenter located in the offshore SW of Sumatra mainland, occurred at the interface of the Indian and Eurasian plates, where the former subducts beneath the Eurasian plate all along the AndamanSumatra Arc. At this region, the Indian plate moves toward NE at the rate of $6 \mathrm{~cm} / y e a r$ relative to the Eurasian plate, and results in an oblique convergence at the Sunda trench. This mega event and the associated aftershock activity highlighted the role of tectonics in understanding and monitoring the marine geohazards, which may sometimes turn into large-scale calamities. Further, the event also raised considerable concern to many Indian Ocean rim countries in formulating a viable mechanism to provide early warning systems in coastal regions on such major events.

The main objective of this Special Issue entitled "Tectonics of Bay of Bengal and Arabian Sea with special emphasis on coastal and marine geohazards" is to bring together 
the recent research work carried out on marine geohazards in the Bay of Bengal and Arabian Sea particularly along the Eastern and Western Continental Margins of India, Andaman-Sumatra Arc/Trench in the Bay of Bengal, and the Makran coast in the northern Arabian Sea.

Initially, we received 13 research papers related to the theme of the Special Issue that were put through the peer reviewing process by two potential referees for each research paper. The referees' reviews helped to sharpen the ideas and improve the quality of the manuscripts. Out of the 13 papers, 8 papers were finally selected for this special issue. These include five papers dealing with various aspects of seismogenesis, structural heterogeneity and tsunami-related studies in the Andaman-Sumatra region, one paper on 3D seismic structure in Kachchh region affected by the 2001 Bhuj earthquake and two papers related to the geohazard analysis of the eastern Indian offshore. A brief summary of the papers is presented in the following paragraphs.

Jaiswal et al. carried out a detailed analysis of aftershock sequences of December 2004 and March 2005 giant Sumatra doublet events. The authors in their study observed that the energy released by these aftershocks was not significant in comparison with their respective main shocks, whereas, the strain release was substantial. Both "b" and "p" values estimated for the aftershock sequences indicate normal heterogeneity, stress distribution, and normal rate of decay of aftershocks. Further, the authors also analyzed tide gauge and wave height records of September 2007 event and modeled minor tsunami generated by this event. The authors tested the ability of TUNAMI-N2 model in capturing such minor events and found that minor tsunami phases could be captured by the model.

Sohini Roy et al. analyzed nearly 8,000 relocated events occurred during 1964-2007 in the Andaman-Sumatra subduction zone to map fractal correlation dimension (Dc) and b-values along the arc and found to be useful in understanding the subduction zone earthquake characteristics. The authors noticed higher Dc and b-values along the trench region and lower Dc and near normal b-values along the fore-arc zone, which correlate with the trench parallel active fault systems. Apart from this expected trend, they could map several pockets of very low Dc and b-values and inferred as more stressed or asperity zones where intermediate to strong earthquakes nucleate.

In order to understand the role of fluid injection on their occurrence and migration path, Basab Mukhopadhyay et al. analyzed the aftershock sequence of December 26, 2004 mega thrust earthquake and the major swarm event of January 2005 within it from the viewpoint of pore fluid diffusion process. The analysis of $\mathrm{r}-\mathrm{t}$ plots computed by them suggests that elevated pore pressure triggers the aftershock sequences including 2005 swarm following the Sumatra earthquake, may have reactivated preexisting fault planes, and produced sites for seabed rupturing. The results have been discussed in light of subduction structure, its implication on the locations of submarine slides and marine geohazards in the Andaman region.

Mishra et al. made use of the seismic records of aftershock events in the AndamanSumatra region and carried out 3D P-wave tomography below Andaman and Nicobar Islands. Their study revealed strong lateral velocity heterogeneities at different depths in the region and reflects asperities that manifest as seismogenic zones. The authors discussed various aspects of velocity heterogeneity as well as seismic vulnerability below Andaman and Nicobar Islands and highlighted the significance of such data in earthquake hazard mitigation models.

Narayana presented a detailed analysis of various geomorphic features associated with 2004 mega thrust earthquake followed by triggered tsunami event using the pre- and postearthquake IRS-P6 LISS III satellite images. He identified several areas that have 
undergone uplift or subsidence along the Andaman and Nicobar Islands and concluded that the main Andaman Islands experienced uplift along the northwestern region and subsidence in the southeast, large-scale geomorphic changes due to extensive erosion/subsidence in the Nicobar region.

Singh et al. presented detailed 3D velocity structure below the source region of 2001 Bhuj earthquake in the Kachchh rift basin using a completely new data set of $7560 \mathrm{P}$ - and $\mathrm{S}$-wave arrival times. They interpreted the occurrence of $2001 \mathrm{Bhuj}$ event on a hidden fault triggered by fluids at a depth of $20-25 \mathrm{~km}$ and stressed that the source region saturated with fluids might have facilitated several seismogenic faults to generate micro- to moderate earthquakes.

Bastia et al. identified various geohazard features in the slope and deep water areas along the eastern offshore of India using the multibeam bathymetry, side scan sonar data and seismic attribute maps from 3D seismic data. They have categorized the geohazards in the region as slope instability, slope canyons, shallow gas, mass transport complexes, sediment waves, gas hydrates, mud volcanoes, and shallow faults and highlighted that identifying such regions would immensely help in minimizing the risk of shallow hazards during exploration, drilling, and installation activities in offshore areas.

Rima Chatterjee et al. in their paper presented the results of pore pressure analysis of five deep-sea wells in the Krishna-Godavari basin. Their analysis indicates the presence of over pressure zone, which can act as potential geohazard during drilling. The application of such studies in deep-water hydrocarbon exploration and production was also discussed by the authors.

Much work remains to be done in understanding the tectonics of Bay of Bengal and Arabian Sea to address coastal and marine geohazards of the region. It is expected that this special issue will draw attention of the geoscientific community, the need for a concerted effort in understanding the marine geohazards in the northern Indian Ocean. Such studies will also gain importance in view of the large scale exploration activities in the near shore and deep offshore areas of the margins in the region.

We sincerely thank Mr. Petra van Steenbergen, Senior Publishing Editor, and other members of the Editorial Board of the Journal "Natural Hazards" for providing us this opportunity. We would like to express our thanks to all contributors of this Special Issue as well as to the esteemed reviewers for sparing their valuable time. We are thankful to Prof. Vladimir Schenk, Coordinating Editor to the Special Issue for his guidance, suggestions, and support.

We are especially thankful to Prof. Tad S. Murty for proposing initially this topic for the Special Issue. Ms. Ayrene Dialogue and Ms. Preetha Arulmohan from the Editorial Office of Springer have helped us in handling online of all the matters related to this Issue.

\section{References}

Ajay KK, Chaubey AK, Krishna KS, Rao DG, Sar D (2010) Seaward dipping reflectors along the SW continental margin of India: evidence for volcanic passive margin. J Earth Syst Sci 119:803-813

Chaubey AK, Dyment J, Bhattacharya GC, Royer JY, Srinivas K, Yatheesh V (2002) Paleogene magnetic isochrons and paleo-propagators in the Arabian and Eastern Somali basins, Northwest Indian Ocean. In: Clift PD, Kroon D, Gaedicke C, Craig J (eds) The tectonic and climatic evolution of the Arabian Sea region, vol 195. Geological Society, London, Special Publications, pp 71-85

Curray JR, Munasinghe T (1989) Timing of intraplate deformation, northeastern Indian Ocean. Earth Planet Sci Lett 94:71-77 
Curray JR, Emmel FJ, Moore DG (2003) The Bengal Fan: morphology, geometry, stratigraphy, history and processes. Marine Petrol Geol 19:1191-1223

Kolla V (2007) A review of sinuous channel avulsion patterns in some major deep-sea fans and factors controlling them. Marine Petrol Geol 24:450-469

Krishna KS, Ramana MV, Gopal Rao D, Murthy KSR, Malleswara Rao MM, Subrahmanyam V, Sarma KV, Sarma KVLNS (1998) Periodic deformation of oceanic crust in the central Indian Ocean. J Geophys Res 103:17859-17875. doi:10.1029/98JB00078

Krishna KS, Michael L, Bhattacharyya R, Majumdar TJ (2009) Geoid and gravity anomaly data of conjugate regions of Bay of Bengal and Enderby Basin: new constraints on breakup and early spreading history between India and Antarctica. J Geophys Res 114: B03102. doi:10.1029/2008JB005808,1-21

Lay T et al (2005) The great Sumatra-Andaman earthquake of 26 December 2004. Science 308:1127-1133

Murthy KSR, Subrahmanyam V, Subrahmanyam AS, Murty GPS, Sarma KVLNS (2010) Land-ocean tectonics (LOTs) and the associated seismic hazard over the Eastern Continental Margin of India (ECMI). Nat Hazards 55:167-175. doi:10.1007/s11069-010-9523-8

Neprochnov YP, Gopal Rao D, Subrahmanyam C, Murthy KSR (1998) Intraplate deformation in the Central Indian Ocean Basin. Mem Geol Soc India 39:233-236

Radha Krishna M, Verma RK, Purushotham AK (2002) Lithospheric structure below the eastern Arabian Sea and adjoining West Coast of India based on integrated analysis of gravity and seismic data. Mar Geophys Res 23:25-42

Rajendran CP (2000) Using geological data for earthquake studies: a perspective from peninsular India. Curr Sci 79:1251-1258

Ramana MV, Krishna K, Ramprasad T, Desa M, Subrahmanyam V, Sarma KVLNS (2003) Structure and tectonic evolution of the northeastern Indian ocean The Indian Ocean-a perspective. In: Sengupta R, Desa E (eds) 2, pp 731-816

Royer JY, Chaubey AK, Dyment J, Bhattacharya GC, Srinivas K, Yatheesh V, Ramprasad T (2002) Paleogene plate tectonic evolution of the Arabian and Eastern Somali basins. In: Clift PD, Kroon D, Gaedicke C, Craig J (eds) The tectonic and climatic evolution of the Arabian Sea region, vol 195. Geological Society, London, Special Publications, pp 7-23

Storey CB (1995) The role of mantle plumes in continental break up: case histories from Gondwanaland. Nature 377:301-308 